\title{
The European Youth Guarantee: labor market context, conditions and opportunities in Italy
}

\author{
Francesco Pastore
}

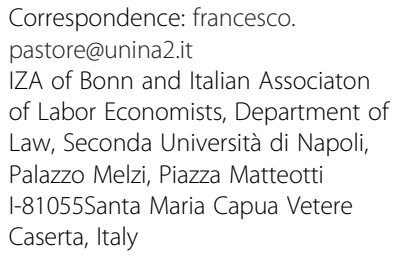

Correspondence: francesco. pastore@unina2.it

IZA of Bonn and Italian Associaton of Labor Economists, Department of Law, Seconda Università di Napoli, Palazzo Melzi, Piazza Matteotti 1-81055Santa Maria Capua Vetere Caserta, Italy

\section{Introduction}

Young people are bearing most of the social cost of the current economic and financial crisis, especially in the Southern and Eastern European member states of the European Union (EU). In Italy, the youth unemployment rate has been escalating from about $20 \%$ in 2007 up to a historical peak of $44.2 \%$ in 2014 . It is, however, from the last months of 2011 that the crisis translated from the production sector into the labor market, causing most of the recent massive increase in unemployment (Figure 1). The Italian youth unemployment rate is, hence, not far below the rates in Spain and Greece (for a recent assessment of the youth labor market problem and school-to-work transition system (SWTS) in these countries, see Pastore, 2012; Rocha Sanchez 2012; Tubadji, 2012; Cahuc et al., 2013; Dietrich, 2013; Bell and Blanchflower, 2015). The EU as a whole and the individual EU member states feel that they should do something to help young people cope with the crisis.

Based on a proposal originally formulated by the European Socialist Party, the EU Parliament and the other EU institutions have approved a program called European Youth Guarantee (EYG since now), which implies the (moral, if not legal) "obligation" for each member state to provide young people with a job, training or educational opportunity within four months from the beginning of their unemployment spell. As discussed at more length in Section 1, the Scandinavian model of school-to-work

(C) 2015 Pastore; licensee Springer. This is an Open Access article distributed under the terms of the Creative Commons Attribution License (http://creativecommons.org/licenses/by/4.0), which permits unrestricted use, distribution, and reproduction in any medium, provided the original work is properly credited. 


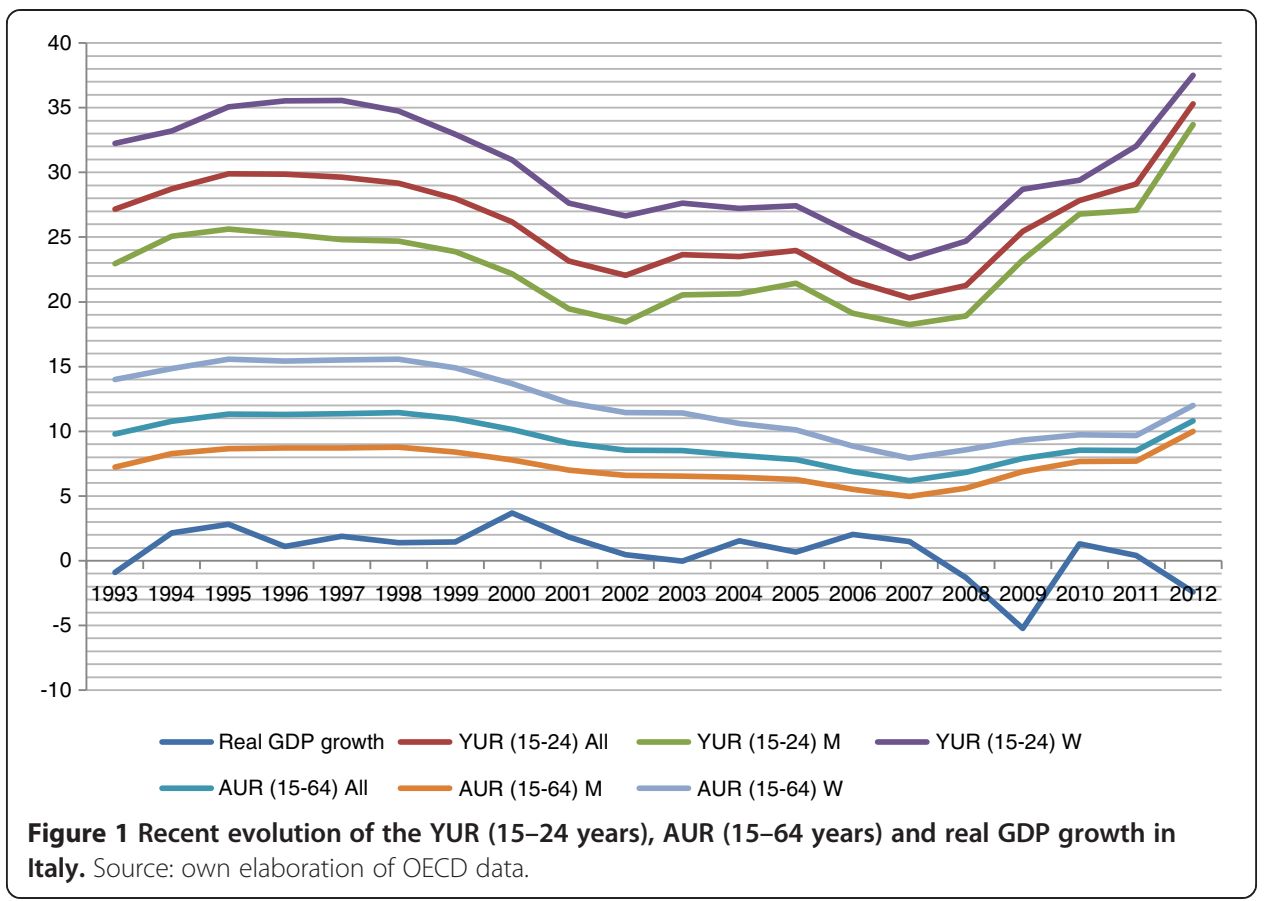

transition clearly inspires the EYG. The program has already been recently implemented in Germany, Austria, the Netherlands and Poland.

This essay aims to discuss the macroeconomic conditions under which the program is implemented and to highlight the necessary institutional conditions to be met in order for the EYG to be successful. To such an end, Section 2 will give a tour d'horizon on the current status of the national debate on youth unemployment. In order to fully understand the context of implementation of the program, the section will discuss the main political positions that emerged in the last elections. This should allow for further understanding of the momentum that the Eurosceptic protest is gaining in Italy and the need to address it not only at a micro-, but also at a macroeconomic level. In turn, this requires also redefining the Maastricht criteria and also involving the European Central Bank in the fight against youth unemployment. In other words, it is vital to discuss the terms of the debate on supply-side versus demand-side programs against youth unemployment and the issue of where (new) jobs could be coming from. The main conclusion is that macroeconomic policy - both fiscal and monetary - is important and should be discussed again. Nonetheless, in addition, the institutions regulating the labor market and the overall school-to-work transition system in particular should also be reformed. Accordingly, Section 3 will deliver an assessment of the microeconomic conditions that should be met in order for the EYG to be successful in Italy. Some discussion of the issues dealt with will be given in the final section together with summary remarks.

\section{The EYG program: an assessment}

In Italy, the EYG is perceived as very far away, a kind of ideal model or just a dream, a dream that is hard to implement because Italy does not have the labor market 
institutions that are necessary to make the EYG work properly and also because it is a foreign body in the country's welfare state tradition.

As Pastore (2015) argues, in Mediterranean countries, it is almost entirely up to individuals and their families to choose the best educational attainment level and an effective school-to-work transition strategy. Public Employment Services (PESs henceforth) are very inefficient in Italy. Pro-active schemes cover only a very small share of the young people in need and are of very low quality. Much too often, a temporary employment contract is the only chance offered to them.

Young people have accepted application of the EYG in Italy with a lukewarm reaction. According to the data provided in the last weekly monitoring report of the Ministry of Labor (2015), as late as in mid-February 2015, about 11 months from the beginning of the program, slightly more than 400,000 young people (aged 15-29) have joined the project out of 1,700,000 young not in employment education and training (NEETs henceforth). Only 151,000 of the registered users have undergone the welcome meeting, only 12,000 of them have used the second level orientation meetings and about 8,000 have entered a pro-active measure. These numbers represent only $9.2 \%$ of those undergoing the welcome meeting, $3 \%$ of the registered users, and $0.7 \%$ of the target population, respectively. In other words, the term of four months from the beginning of the unemployment spell is not dealt with for almost anyone.

Figure 2 shows the evolution of registrations to the EYG program since its beginning, split by gender. The initial enthusiasm that led about 80,000 young people to register in a few weeks has since much lessened. After the summer, it had risen again for a couple of months to continuously shrink since then, probably as a consequence of the disappointing news coming from the press rather than from depletion of the stock of the target population, which still remains huge.

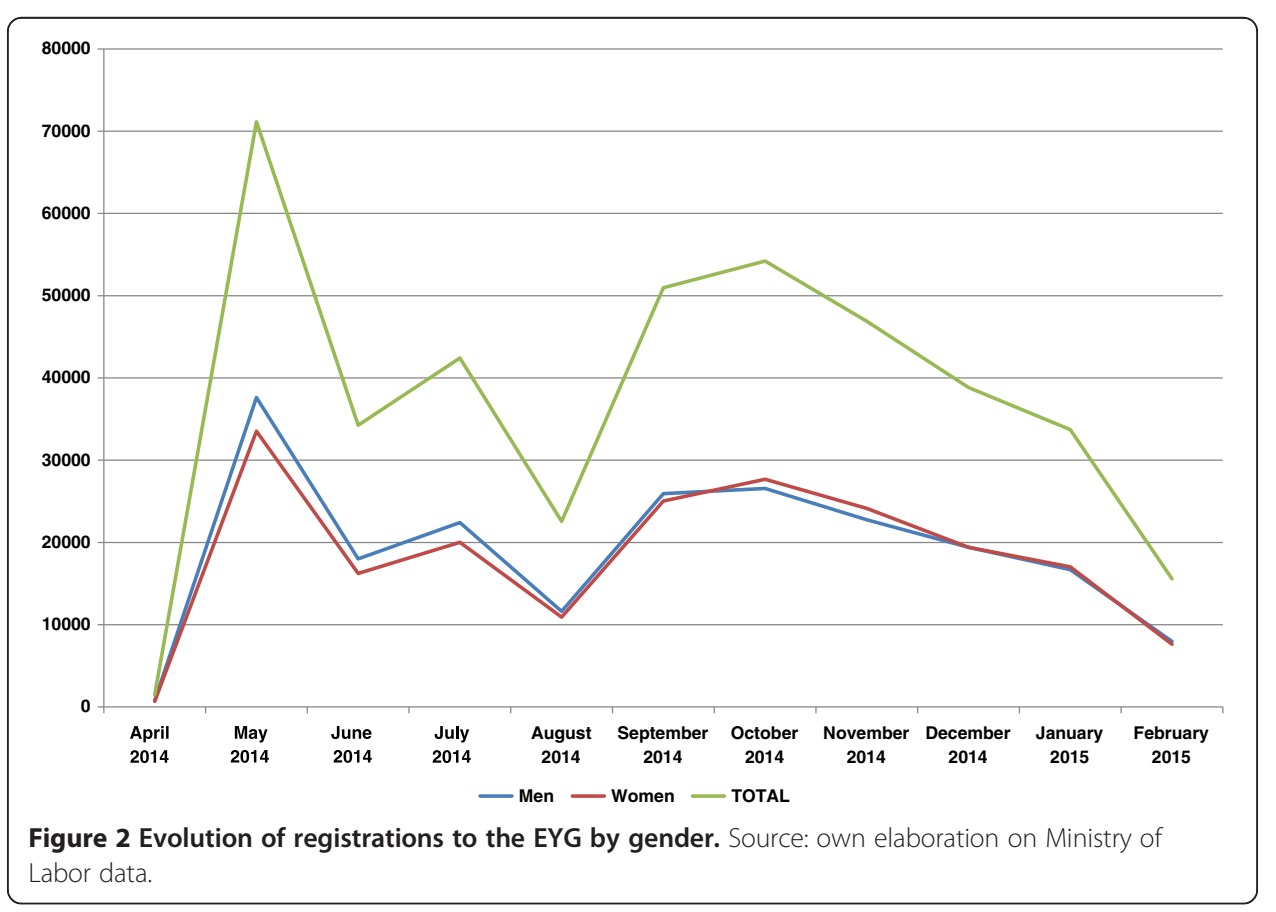


Only very few tangible job opportunities were provided to registered users. Official statistics show that about $74 \%$ of the jobs offered were fixed-term contracts. Permanent jobs were only $11.5 \%$ of the total. Despite being mentioned by all EU Commission documents as key to the success of the EYG, traineeships were only $8 \%$ and apprenticeships were only $1.7 \%$ of the total.

Analysis of the available statistics shows that there are no significant differences by gender. Of the three typical age groups of young people, not surprisingly, the young adults, aged $20-24$ are the most numerous, with about $52 \%$ of the total. The teenagers, which are often still at school, are less than $10 \%$, the rest being aged 25-29, some of which have already found a job in another way.

Only about $39 \%$ of the young people registered in the program where actually interviewed and subjected to profiling, with dramatic differences across regions in the ability of local employment offices to organize the profiling of such a large number of individuals (Figure 3). The least efficient regions where located not only in the South (especially Calabria and Campania), but also in the Center-North (especially Piedimont and Liguria). Typically, the most efficient regions are the central ones (Emilia Romagna, Toscany, Umbria, Marche), except for Lazio, which is about average. The strong regional differences are important factors able to jeopardize the program, as explained at more length in what follows. It is therefore not by chance that the first intervention of the government led by Matteo Renzi in the field of employment services has been the introduction in the Jobs Act of a national agency with the aim of coordinating the activities of public and, to some extent, also private employment services existing in the country. Currently, and since the 2001 constitutional reform of chapter V of the Italian constitution, regional authorites have been in charge of training and employment policy, which has created 20 different labor markets with different rules, institutions and administrative capacity.

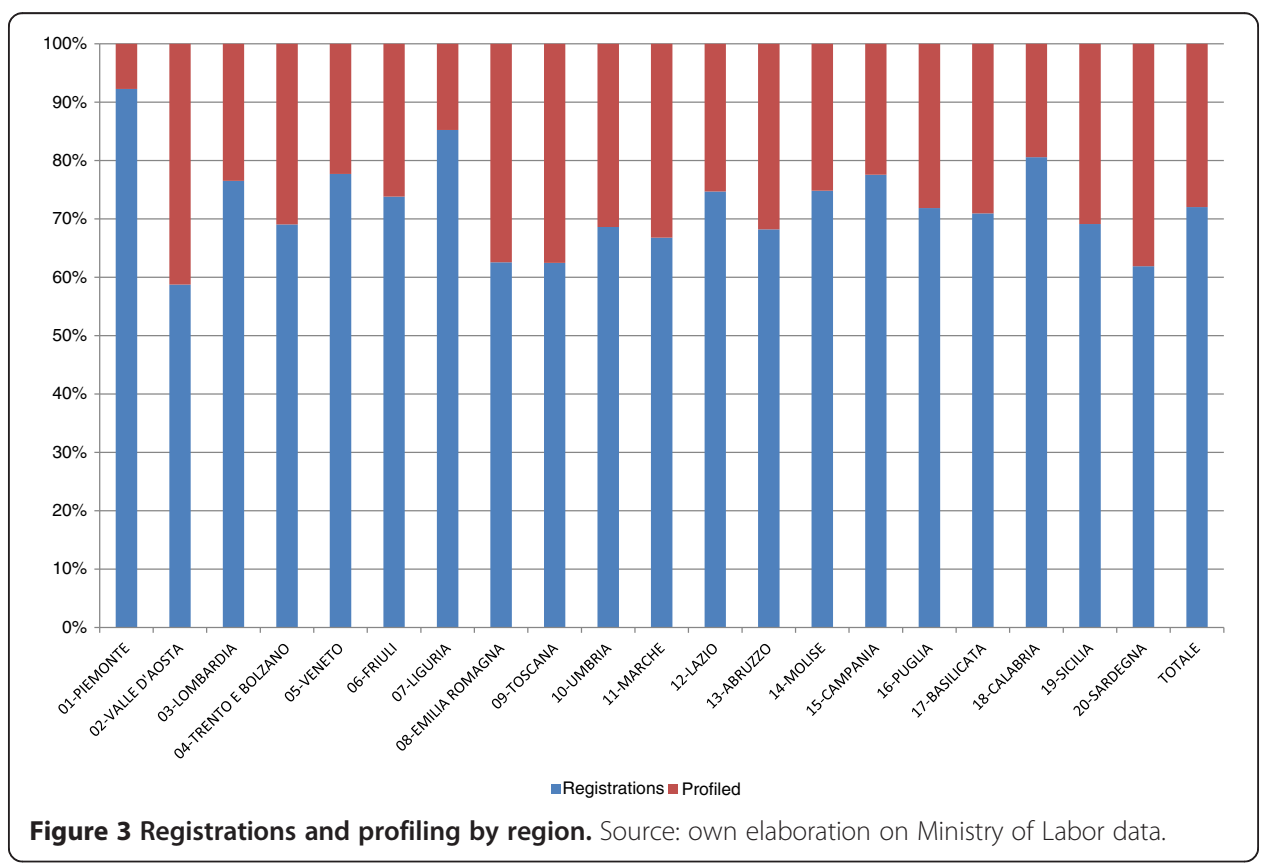


By its very nature, the EYG is implemented in a different way in every country of the EU according to the strength and weaknesses of the country's labor market institutions (Besamusca et al. 2012). Although there is no comparative information on the implementation of the EYG, it is clear that, for reasons that will be discussed at length in what follows, the program is hardest to implement in southern European countries, and the few statistics provided above show that Italy is no exception to this scheme.

In his recent report, Tiraboschi (2015) lists a number of shortcomings of the EYG in Italy:

a) The national agency in charge of the program implementation (Struttura di Missione) was dismissed in December 2014, but at the moment, there is no alternative institution in charge of the program. Probably the government is planning to attribute control of the program to the soon to be found national agency for employment services;

b) Against the EU suggestions, the 4 months of the guarantee are computed from the signing of the deal between PES and program participants, but, in fact, much more time is used for the few who participate in the program;

c) Official websites report job vacancies which were already published elsewhere and often are not for young people, but require several years of work experience;

d) The authorities consider paying any deal, not only those who survive after some months;

e) Despite the EU promotion to invest especially in apprenticeship contracts, only $4.5 \%$ of the funds are used for that, and some regions do not spend any money for apprenticeship (e.g., Liguria, Piedimont, Sardinia and Veneto).

Together with the bureaucratic nature of meetings and talks these numbers are likely to discourage further registrations, which, as noted above, have already dramatically reduced on a monthly basis. This is a confirmation of our concerns regarding the inefficiency of the institutions responsible for the organization of the labor market. This also confirms the lack of interconnectedness between educational institutions and the world of work.

\section{The outlook}

\subsection{Raising euroscepticism}

The Italian electorate, especially the young component, feels strongly dissatisfied with the government policy and also with the EU policy. This explains why the last political and European elections were perceived as a test, not between center-left against centerright, but rather between those parties who favored the EU policy and the Euro and those who declared to be against European (or German) austerity. For the first time in Italian history, several parties were explicitly Eurosceptic: first of all, the so-called "5star movement" (Movimento 5 Stelle; 5SM henceforth), the party led by Beppe Grillo; but also Lega North; and, with the usual political ambiguity, the People of Freedom, the party led by Silvio Berlusconi ${ }^{1}$. A number of other smaller parties were also trying to pick up on the anti-euro protest.

In fact, these Eurosceptic parties almost won the political elections in 2012; the former won the European elections in 2014. In the 2012 political elections, Grillo's 
movement, which declared the intention to go back to the Italian lira, became, together with the Democratic Party, the first political party to gain about $25 \%$ of the votes at their first appearance in the political arena. This result was quite surprising for a number of reasons. First, the opinion polls that were circulating before the elections invariably favored the Democratic Party led by Pier Luigi Bersani as the undisputed winner of the elections. Second, and paradoxically, despite the enormous political responsibility for the November 2011 Italian financial crisis, the People of Freedom, the party led by Berlusconi, managed almost to win the elections by promising to return to tax payers the IMU (Imposta Municipale Unica, a municipal property tax) introduced by the government led by Mario Monti and supported by the troika to recover the public deficit accumulated during Berlusconi's previous government.

Conversely, the Democratic Party, which supported the EU strategy and was expected to get the payoff of the political and financial disaster caused by Berlusconi, won by only 200,000 votes and, therefore, got the majority of seats in the Camera, but not in the Senate ${ }^{2}$. The party of Mario Monti, who hoped to be the alternative to Berlusconi for the center-right electorate obtained only a meager $10 \%$ of the votes. The reason of the defeat of supporters of the EU strategy is to be found in the aptitude of the vast majority of the electorate who feels that they already pay too many taxes. In fact, probably because of tax evasion, the actual tax payers, especially wage employees, pay an unbearable amount of taxes, more than in the Scandinavian countries, but they receive public services which are of far lower quality than their Scandinavian peers.

Most young people feel that politics, also due to EU constraints, are not going to make the necessary changes (Diamanti 2012). Young people importantly contributed to the electoral success of Grillo's movement. They massively voted for protest and against the so-called EU austerity policy: about $47 \%$ of the young people aged 18-24 voted M5S. For instance, they found Grillo's proposal of a means-tested income support scheme for the unemployed important in a period of dramatic economic crisis. It would be certainly a novelty in a country where there is no income support scheme for first time job seekers (Albertini et al. 2013; Paparo and Cataldi 2013).

Another (unintended) effect of Grillo's exploit in the 2012 political elections was the resignation of Pier Luigi Bersani and the ensuing victory of Matteo Renzi as the leader of the Democratic Party. On the 22nd of February 2014, Renzi managed to become the head of the government instead of Enrico Letta, whom Renzi considered not in line with the boost he wanted to give to the government before the next political elections. His government was already able to implement a number of reforms in the early weeks of his mandate, which allowed him to gain an outstanding 40\%, a record for the Democratic Party, in the May 2014 European elections. Since then, the Renzi government is implementing a number of reforms, including the EYG, the Jobs Act, electoral reform, constitutional reforms, to mention a few, which have maintained the relatively high position of the new Democratic leader in opinion polls. Nonetheless, the persistently unsatisfactory economic and financial situation is in the meantime increasing euroscepticism in the country. In fact, if the Renzi reforms are not able to change much, it means that it is the Euro itself that is causing the crisis. This argument is gaining momentum, in favor of the 5SM and Lega North, whose young leader, Matteo Salvini, was publicly endorsed by Berlusconi as his possible political successor. 


\subsection{Austerity and the euro}

Many people believe that raising taxes cannot be the solution to fight the public debt considering the size of the debt itself. In the meantime, the fight against tax evasion has not been very successful. In the current situation, tax pressure is so high that raising further taxes would mean, as Monti's government has proven and Monti himself has declared, further increasing, not reducing the debt (Figure 4).

In addition, there is growing concern that some public spending, the so-called "productive" spending, should be permitted, especially in a period of dramatic economic crisis like the one we are in. By "productive" public spending, we mean the growthenhancing components of it. It is necessary to define policies aimed at restructuring public spending in depth by reducing the weight of public sector branches that are less effective in reducing the impact of the crisis and favoring the other branches. Public spending is needed to make the country cope with the crisis but also to re-launch the economy in the long-run, which requires investing in education, research and development, and public infrastructure ${ }^{3}$.

In fact, this was the argument that Renzi raised during his 2014 Italian Presidency of the EU. In January 2015, together with Gianni Pittella, the leader of the EU Socialist Party, the newly elected President of the EU Commission, Jean-Claude Junker, promised to implement a development plan at the EU level of 300 billion euros, financed by the European Central Bank (ECB since now; see Pittella, 2015). At least in principle, this is certainly a u-turn in the EU policy regarding fiscal and monetary stimulus, and hopefully it will be the beginning of a new way of thinking of the role of the EU institutions in aggregate management at the EU level.

In the case of Italy, the long-term single cause of the economic crisis is to be found in the move from an economy based on so-called competitive devaluations to one based on a strong currency, as well as the wrong economic policy that both the country's government and the EU as a whole have (not) implemented to cope with this change. Moreover, as Aristotelous (2006) shows, Italy was unable to gain from the introduction of the Euro or in terms of greater trade integration with the rest of the Euro area.

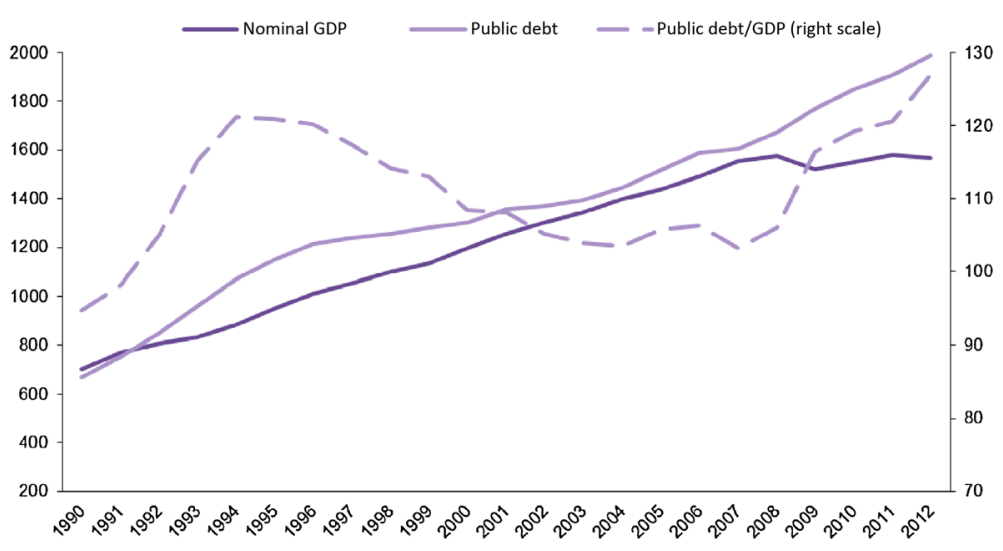

Figure 4 Public Debt, GDP and Debt to GDP ratio (1990-2012; billion euros and shares). Source: ISTAT data. 
In fact, the Italian economy was located at the lower tail of the distribution of growth rates of the European economies already before the financial crisis started. As Figure 5 shows, labor productivity has been stagnating at least from the early 1990s.

These disappointing outcomes are surely also the consequence of bad economic policy. It was not infrequent during the last two decades or so to hear Giulio Tremonti, the Minister of the Economy in 8 out of 10 years of the 2000s, claiming that the low spending in education, $R \& D$ and innovation typical of Italy is due to the peculiar industrial structure of the economy, which is traditional and based on small-sized firms; therefore, any public intervention to counteract this outcome is bound to fail.

Another cause of the lack of intervention to stimulate structural change was also fiscal austerity and the need to maintain public finances as stable as possible in a situation where the public debt has been well above 100\% of GDP for all of the 2000s. Austerity has had severe consequences for the countries with the highest public debt. Austerity is probably also due to a mistrust in the ability of national governments to implement the right reforms, but then instead of forbidding public spending at all, it would be better to introduce some form of conditionality while providing support to national level industrial policy.

\subsection{The on-going labor reforms}

The national debate on youth unemployment in Italy is fortunately overcoming some of the refrains of the past, which had become like blind spots. The emphasis on labor market flexibility is perhaps the most important. The recent reform of the labor market, so-called Fornero Act (Law 92/2012) from the name of the Minister of Labor who proposed it, Elsa Fornero, has been one of the last attempts to further flexibilize the Italian labor market, although in the name of flexicurity ${ }^{4}$. On the one hand, it has made temporary work more costly and, on the other hand, it has made permanent work cheaper by reducing the constraints on firing decisions based on article 18 of the 1970 Labor Code. On the one hand, entrepreneurs have been obliged to declare the reason for the temporary nature of the contract and to pay higher social security contributions to temporary workers than to permanent workers. On the other hand, firing decisions

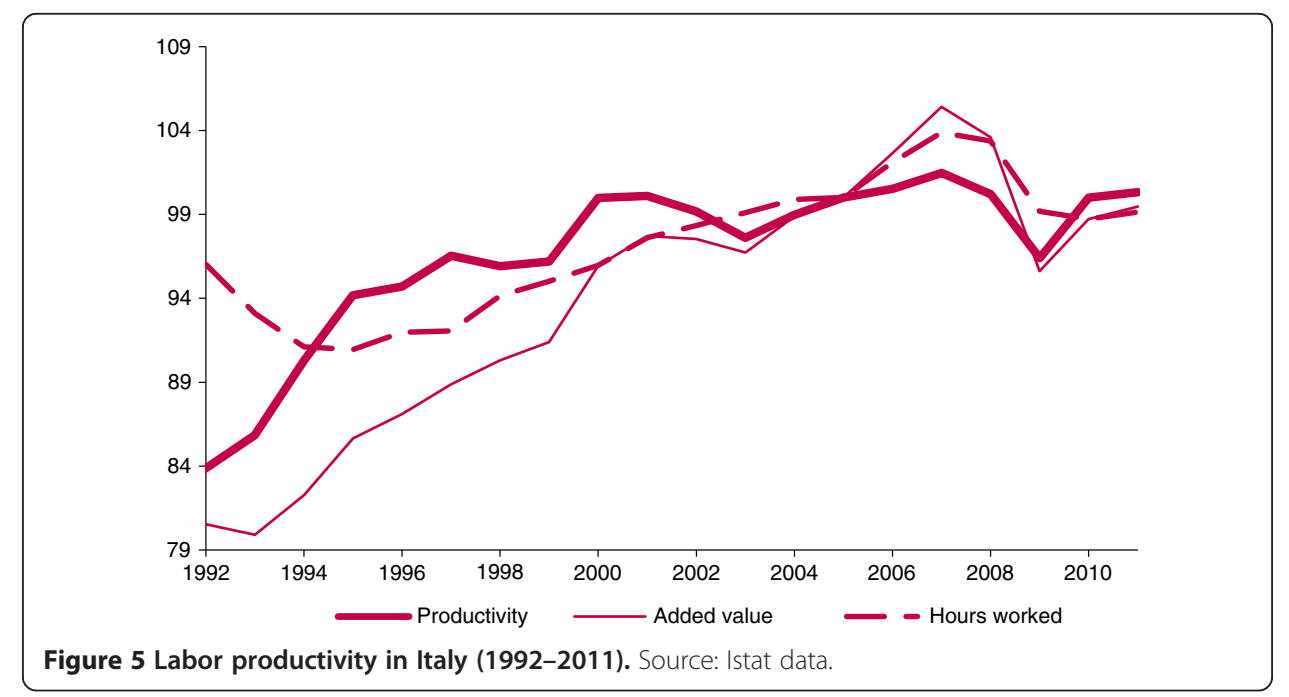


have become a little bit easier. The Fornero Law has had only a limited impact on employment, despite the great expectations. In fact, by making temporary work more difficult to renew, over 200,000 temporary contract jobs have been immediately discontinued, which also could be attributable to the on-going economic crisis (Boeri 2013).

The public debate has, in fact, immediately highlighted the need for new labor market reforms. In fact, already in 2014, the Parliament had approved the Jobs Act with a mandate to the Renzi government to implement important changes in the labor legislation, such as, among others: a) the abolition of the obligation for the employer to hire again workers fired for economic reasons (so-called reintegra sul posto di lavoro) as based on art. 18 of the Labor Statute of 1970; b) introduction of the so-called single labor contract, a contract with increasing guarantees for workers by the years of employment (contratto unico a tutele crescenti) ${ }^{5}$; and c) the ensuing abolition of temporary work contracts and project work.

Beside the reform of the Fornero law, there seems to be awareness of the need to overcome the emphasis of the past debate on labor market flexibility. Several members of the Letta and Renzi government (Carlo Dell'Aringa, Pier Carlo Padoan and so on) have mentioned the need to reduce the cost of labor, especially the wedge, which is particularly high at about $120 \%$ of the net wage, and to reinforce the existing institutions in the labor market (Giubileo et al. 2014). It is not surprising that, although the possible effects are uncertain and probably modest, one of the most welcomed reforms of the Renzi government was the reduction by 80 euros of the wedge of labor incomes, which are under 1,500 euros (Guiso 2014).

For instance, the Jobs Act has explicitly stated the need to overcome the weaknesses of PESs. The aim of the Jobs Act is to introduce flexicurity, meaning not only greater flexibility in the employment protection legislation (EPL henceforth), but also more public intervention to increase the employability of those who lose their job. Spending more on active (ALMP henceforth) and on passive labor market policy (PLMP henceforth) is another core element of flexicurity, but also of the EYG. In fact, as already noted, the latter is based on the Scandinavian school-to-work transition model, which in turn is based on ALMP on a large scale for the jobless young people and is often coupled with some passive income support. ALMP is a tool to provide young people with the work experience and job-related skills they actually need when the educational system is sequential, rather than dual, as it is in both Scandinavian and Southern European countries. As is well-known, in sequential educational systems, building general education is the only mission of the educational system, while work experience should be gained after completing the educational path. Now, the point is that in Southern European countries, including Greece, public and private employment services are very week. In Scandinavian countries, instead, the Ghent system has favored the development of excellent employment services (Pastore 2015).

\section{The conditions for success}

\subsection{The length of the SWT}

As Pastore (2015) notes, the school-to-work transition, namely the move from education to gainful employment, is a complex mechanism which is affected by different organizations and institutions, such as the family, the educational and training system, 
the labor legislation, the PES, the type of PLMP and ALMP. The different way such institutions are modelled importantly affects the ability of young people to fill in their experience gap and therefore find a stable job. EU countries can be clustered in different regimes, although there are also important differences from one country to another within the same regime: a) North-European; b) Central European; c) AngloSaxon or liberalist; d) South European; e) New Member States. Table 1 provides a selfexplaining synoptic view of the differences between these regimes. Giuliani and Pastore (2014; and 2015) show by means of panel data analysis that there is something in the Central-European and liberalist regimes which allows them to have the lowest youth unemployment rate, also after controlling for a number of factors, such as per capita GDP level and growth, share of secondary and tertiary education attainment, degree of EPL, expenditure in PLMP and ALMP.

The simplest indicator of the efficiency of a school-to-work transition is its length. Unfortunately, there is still very little information about the characteristics of SWTRs. Recently, the Eurostat has released new important information on the length of the school-to-work transition as based on two modules of the European labor force survey ${ }^{6}$. The available data reported in Figure 6 focuses only on average values by country and educational level. In addition, they look only at the transition to "the first significant job," meaning a job of at least three months duration in the survey and, hence, not necessarily a permanent job. It shows that there are large differences by country and education attainment level. The slowest countries are the South European and the East European ones. With an average waiting time of 9 months, Italy is second only to Greece in terms of the length of the transition for tertiary graduates. In addition, with an average waiting time of about 13.5 months, it is the 7th in terms of the transition of high school graduates.

This figure, however, is likely to underestimate the overall length of the SWT in Italy. At least two important factors should be taken into consideration for a more realistic account. First, as noted above, the Eurostat data considers only the transition to the first important job, but this may not represent the real end of the transition, especially after the implementation of two-tier reforms and the diffusion of temporary work. Quintini et al. (2007, Table 1) report that in Italy, the length of the transition from education to a permanent job lasts about 44.8 months, a factor of almost 4 with respect to

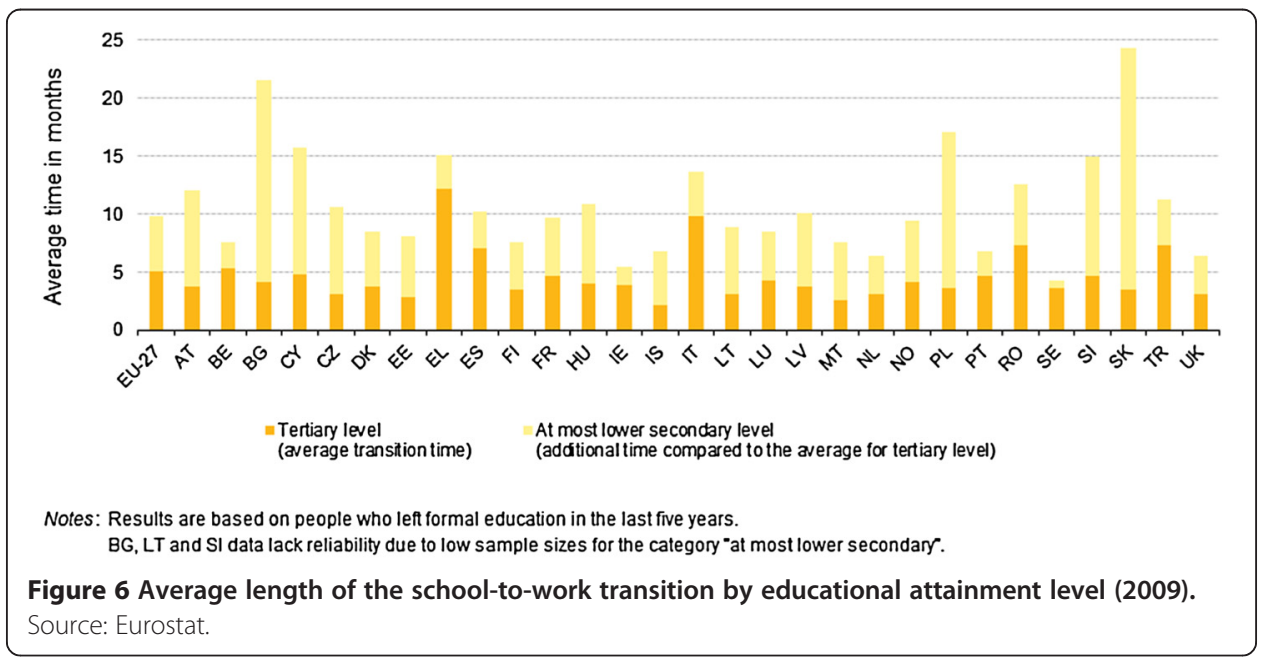


Table 1 Characteristics of school-to-work transition regimes

\begin{tabular}{|c|c|c|c|c|c|}
\hline & Scandinavian & Central-European & Anglo-Saxon & South-European & East.European \\
\hline $\begin{array}{l}\text { Educational } \\
\text { system model }\end{array}$ & Sequential & Dual & Sequential & Sequential & $\begin{array}{l}\text { Sequesntial, except for some } \\
\text { countries which follow the dual } \\
\text { system (Hungary and some } \\
\text { South-European countries) }\end{array}$ \\
\hline $\begin{array}{l}\text { Mobility between } \\
\text { curricula }\end{array}$ & Rigid & $\begin{array}{l}\text { Very rigid and segmented } \\
\text { school track }\end{array}$ & $\begin{array}{l}\text { Flexible, both at the school } \\
\text { and at the university level }\end{array}$ & $\begin{array}{l}\text { Flexible in principle, } \\
\text { but rigid in practice }\end{array}$ & Rigid \\
\hline $\begin{array}{l}\text { Education } \\
\text { attainment }\end{array}$ & $\begin{array}{l}\text { High shares of secondary and } \\
\text { tertiary education attainment }\end{array}$ & $\begin{array}{l}\text { High shares of secondary and } \\
\text { tertiary education attainment }\end{array}$ & $\begin{array}{l}\text { High shares of secondary and } \\
\text { tertiary education attainment }\end{array}$ & $\begin{array}{l}\text { Low education } \\
\text { attainment }\end{array}$ & $\begin{array}{l}\text { High, but with some } \\
\text { exceptions }\end{array}$ \\
\hline ALMP & $\begin{array}{l}\text { Very common for every } \\
\text { young NEET }\end{array}$ & $\begin{array}{l}\text { Common as a last resort after high } \\
\text { vocational and professional school }\end{array}$ & $\begin{array}{l}\text { Last resort, to be used only if leading } \\
\text { quickly to work }\end{array}$ & $\begin{array}{l}\text { Marginal and } \\
\text { underdeveloped, }\end{array}$ & Marginal in most countries \\
\hline PES (see Table 2) & $\begin{array}{l}\text { Relatively efficient, well-endowed } \\
\text { in terms of resources, based } \\
\text { on the Ghent model }\end{array}$ & $\begin{array}{l}\text { Strong presence of the unions, } \\
\text { integrated with the school system, } \\
\text { relatively efficient }\end{array}$ & $\begin{array}{l}\text { Centrally managed, little role of trade } \\
\text { unions, principle of horizontal } \\
\text { subsidiarity }\end{array}$ & $\begin{array}{l}\text { Decentralized, lack of } \\
\text { coordination, insufficient } \\
\text { resources }\end{array}$ & $\begin{array}{l}\text { Relatively inefficient, insufficient } \\
\text { resources }\end{array}$ \\
\hline PLMP & $\begin{array}{l}\text { Unemployment benefits for a } \\
\text { limited period of time and } \\
\text { awarded on a contractual } \\
\text { basis, linked to some program, } \\
\text { plus means-tested income } \\
\text { support after a year, awarded } \\
\text { by PES as based on the } \\
\text { Ghent model }\end{array}$ & $\begin{array}{l}\text { Similar to Scadinavian } \\
\text { countries, }\end{array}$ & $\begin{array}{l}\text { Similar to the Scandinavian countries, } \\
\text { but state-based }\end{array}$ & $\begin{array}{l}\text { Unemployment benefits } \\
\text { but no means-tested } \\
\text { income support }\end{array}$ & $\begin{array}{l}\text { Unemployment benefits and } \\
\text { means-tested income support } \\
\text { in some countries }\end{array}$ \\
\hline Role of the family & Marginal & Marginal & Marginal & Central & $\begin{array}{l}\text { Marginal except for the } \\
\text { South-East-European } \\
\text { countries and the }\end{array}$ \\
\hline $\begin{array}{l}\text { EPL (based on the } \\
\text { OECD } \\
\text { assessment) }\end{array}$ & $\begin{array}{l}\text { Rigid, but becoming slowly } \\
\text { more flexible }\end{array}$ & $\begin{array}{l}\text { Rigid, but becoming slowly } \\
\text { more flexible }\end{array}$ & Very flexible & $\begin{array}{l}\text { Rigid, but with two-tier } \\
\text { reforms }\end{array}$ & $\begin{array}{l}\text { Quite flexible, with two tier } \\
\text { reforms }\end{array}$ \\
\hline
\end{tabular}


the Eurostat data. The reason of such long SWT is clearly the lack of sufficiently well developed work related skills to become employable in the eyes of employers, which is due, in turn, to the lack of occasions to gain work experience either during or after the educational period.

Second, the length of the transition should be weighted for the actual length of time that is necessary to obtain a university degree in Italy, one of the world longest, especially in terms of expected values. According to data provided by the Ministry of Education, over $50 \%$ of undergraduate students drop out of college without attaining a degree and too many remain registered with little hope to complete their studies, while some complete their studies only after an outrageously long time. About $40 \%$ of graduates get their college degree with a delay of between 1 and 10 years with respect to the curricular $3+2$ years. According to AlmaLaurea data, the average age at graduation for students starting their university at 18 years is 24 years for the 3-year program and 26.1 years for the $3+2$ program. The reason is the high indirect cost of university education, which in turn depends on unpreparedness of the university system to the deal with the increasingly large number of students who register at the university. Too many young people go to the university without an adequate cultural background, while the data suggests there is a very low attendance rate at courses, heaviness of courses' programs, the presence of "cliff exams" (esami scoglio) and so on (for a more detailed account of the phenomenon called fuoricorsismo, see Aina et al. 2013).

\subsection{Making the EYG work}

Section 1 has shown that the EYG is only virtually in place in Italy if one considers the actual numbers. Indeed, the Italian labor market is poles apart from the social model that is behind the EYG. First of all is the fact that in the Italian system, there is no obligation whatsoever to even help young people to search for a job. The EYG is based on the well-functioning of PESs. The first condition, then, to be met in order to successfully implement the EYG in Italy is one of administrative capacity.

Since 1991, the state sector has lost its legal monopoly over labor intermediation and also for low skill jobs, which it had maintained since 1970. This did not help increase the share of the unemployed who found a job through PESs, actually, just the opposite. Even when in 1997, the Treu Law allowed private agencies to join in the activity of job placement through the PES for temporary contracts, things did not changed much. The Biagi Law of 2003, which strongly encouraged the cooperation between public and private agencies, was not much more successful. Against the expectations of experts and policy makers, despite the reforms implemented, as Mandrone (2011, Table 1) reports, the share of jobs placed through the PES has remained stubbornly low (just above 3\%). This compares to about $7.7 \%$ in the UK and $13 \%$ in Germany.

A possible explanation of the inefficiency of PESs is the lack of available resources, both financial and human. Just to make a quick international comparison, consider Table 2. It reports comparative indicators regarding the PES activities in 2012. The number of unemployed per staff of the PES and the index of efficiency, namely, the number of registered unemployed who found a job in the unit of time, are particularly useful. The efficiency index is just 2.6\%, almost nothing, similar to other South European countries. Instead, the efficiency index is much higher for the Scandinavian 
Table 2 Comparative indicators of PES in EU countries

\begin{tabular}{|c|c|c|c|c|c|c|c|}
\hline Cuntry & $\begin{array}{l}\text { Total number } \\
\text { of offices }\end{array}$ & $\begin{array}{l}\text { Number } \\
\text { of staff }\end{array}$ & ALMP & PLMP & $\begin{array}{l}\text { Number of } \\
\text { unemployed } \\
\text { workers registered } \\
\text { at the PES (2012) }\end{array}$ & $\begin{array}{l}\text { Number of } \\
\text { unemployed } \\
\text { per staff of } \\
\text { PES (2012) }\end{array}$ & $\begin{array}{l}\text { Index of } \\
\text { efficiency } \\
\text { of PES (\%) } \\
(2011)(1)\end{array}$ \\
\hline Austria & 110 & 4.828 & $\mathrm{SI}$ & $\mathrm{SI}$ & 54,0 & 39,2 & 24,4 \\
\hline Brussels & 18 & 866 & $\mathrm{SI}$ & NO & & & \\
\hline Wallonia & 145 & 3.602 & $\mathrm{SI}$ & NO & & & \\
\hline Flanders & 20 & 4.010 & $\mathrm{SI}$ & NO & & & \\
\hline Belgium & 183 & 8.478 & $\mathrm{SI}$ & NO & 48,9 & 43,5 & 12,2 \\
\hline Bulgaria & 252 & 2.500 & $\mathrm{SI}$ & NO & 145,8 & 164,1 & 7,2 \\
\hline Croatia & 122 & 1.315 & $\mathrm{SI}$ & $\mathrm{SI}$ & 246,6 & 206,8 & 5,8 \\
\hline Denmark & 95 & 9.336 & $\mathrm{SI}$ & NO & 14,8 & 23,4 & 22,7 \\
\hline Estonia & 42 & 519 & $\mathrm{SI}$ & $\mathrm{SI}$ & 80,6 & 132,0 & 7,7 \\
\hline Finland & 117 & 3.081 & $\mathrm{SI}$ & $\mathrm{SI}$ & 82,2 & 67,1 & 27,0 \\
\hline France & 1.173 & 49.159 & $\mathrm{SI}$ & $\mathrm{SI}$ & 65,4 & 57,2 & 7,8 \\
\hline Germany & 1.100 & 110.033 & $\mathrm{SI}$ & $\mathrm{SI}$ & 26,3 & 21,1 & 18,8 \\
\hline Greece & 212 & 3.674 & $\mathrm{SI}$ & $\mathrm{SI}$ & 217,1 & 327,7 & 1,5 \\
\hline Ireland & 135 & 6700 & $\mathrm{SI}$ & $\mathrm{SI}$ & 66,4 & 47,2 & 2,9 \\
\hline Italy (2) & 556 & 8.713 & $\mathrm{SI}$ & NO & 254,2 & 314,9 & 2,6 \\
\hline Latvia & 29 & 817 & $\mathrm{SI}$ & NO & 145,6 & 189,8 & 15,0 \\
\hline Lithuania & 94 & 1.441 & $\mathrm{SI}$ & NO & 150,5 & 136,6 & 8,8 \\
\hline Luxembourg & 7 & 343 & $\mathrm{SI}$ & $\mathrm{SI}$ & 43,7 & 37,3 & 36,3 \\
\hline Malta & $n / d$ & 292 & $\mathrm{SI}$ & NO & 23,4 & 39,4 & 12,7 \\
\hline The Netherlands & 36 & 4.365 & $\mathrm{SI}$ & $\mathrm{SI}$ & 130,3 & 107,3 & 9,3 \\
\hline Poland & 358 & 23.163 & $\mathrm{SI}$ & $\mathrm{SI}$ & 92,8 & 75,5 & 6,2 \\
\hline Portugal & 89 & 5.767 & $\mathrm{SI}$ & NO & 110,0 & 149,1 & 9,1 \\
\hline UK & 860 & 77.722 & $\mathrm{SI}$ & $\mathrm{SI}$ & 20,2 & 32,3 & 19,2 \\
\hline Czech Republic & 257 & 9.020 & $\mathrm{SI}$ & $\mathrm{SI}$ & 56,0 & 40,7 & 7,3 \\
\hline Romania & 271 & 2.162 & $\mathrm{SI}$ & $\mathrm{SI}$ & 207,4 & 324,3 & 3,4 \\
\hline Slovak Republic & 47 & 8.949 & $\mathrm{SI}$ & NO & 45,4 & 42,2 & 6,0 \\
\hline Slovenia & 60 & 987 & $\mathrm{SI}$ & $\mathrm{SI}$ & 111,6 & 90,8 & 15,1 \\
\hline Spain (4) & 781 & 21.309 & $\mathrm{SI}$ & $\mathrm{SI}$ & 199,8 & 272,7 & 2,4 \\
\hline Sweden & 321 & 12.560 & $\mathrm{SI}$ & $\mathrm{NO}(3)$ & 17,0 & 32,1 & 55,7 \\
\hline Hungary & 194 & 4.333 & $\mathrm{SI}$ & $\mathrm{SI}$ & 129,0 & 109,8 & 10,5 \\
\hline
\end{tabular}

Source: Cicciomessere (2014, Tab. 3).

(especially Sweden, Finland and Denmark) and Central European countries (especially Germany and Austria). The low efficiency rate is due first of all to the lack of resources. In Italy, there are 314.9 unemployed people for every staff of the PES; the comparable number for the UK is about 32.3 and in Germany about 21.1. Not surprisingly, the Italian ratio has dramatically further increased during the economic crisis, from a high of 150.1 in 2007. The ratio of staff per registered unemployed person is only slightly lower at 254.2.

In addition, the current legislation does not help much in as much as it assigns to PES eminently bureaucratic tasks (see, among others, Cicciomessere and Sorcioni 2007; Giubileo 2011; and 2012; Pastore 2013). The situation should get better with the implementation of the Jobs Act, which should foresee the introduction of a National 
Agency to overcome the lack of coordination among the PES of each province. In addition, the relationship between public and private operators should change from one of competition to one of division of roles, with the public sector having the tasks of profiling, giving guidelines, organizing, monitoring, supervising and evaluating the results, while the private sector executes such services as counseling, insertion, training and so on (Giubileo and Pastore 2012 and 2013a, 2013b, and 2013c).

In a period of dramatically plummeting opportunities in the public sector, with the share of jobs offered falling down from about $29.5 \%$ in the mid-1990s to about $8.6 \%$ in the late 2000s, the percentage of young people who are seeking jobs through their network of family and friends has dramatically further increased from a high of $24.4 \%$ in the mid-1990s to about $35.3 \%$ in the late 2000s. In the meantime, private agencies of temporary work had increased their market share up to $5 \%$ in the late 2000 s (Mandrone 2011).

For all these reasons, the EYG would be, in principle, certainly useful and positive in the case of Italy. It would imply, if not a "legal" obligation, which is hard to even conceive, at least a "moral" obligation that the public sector will play a more active role in the labor market, as is the case in the countries where flexicurity is working. In order for this to happen, though, it is necessary that the PES be endowed with sufficient human and financial resources while being cleaned from bureaucratic burdens which could be assigned to private call centers by paying only a little cost (Giubileo 2012; and Giubileo and Pastore 2012).

A proposal raised in a number of contributions would be to support the EYG by using the EU money coming from different sources, including the structural funds, which are hardly and poorly spent in Italy on small programs whose impact can be claimed to be negligible (without making an evaluation study). If all the money that is spent (and even more the money which is not spent) were used for a single unified and organic reform program of re-launching the role of the PES by assigning to it new tasks and resources under the umbrella of the EYG, the money would be spent in a sounder and more efficient way. This money is currently out of reach because of the low absorption capacity and also because the criteria are very hard to meet, especially for peripheral regions. We are aware of the difficulties that the strict rules regulating the use of European Structural Funds would place in case they were used in the direction of improving the institutions regulating the labor market. But we are also convinced that this would be a more effective way of reaching the declared aims of the EU funds than using them in the way they are currently used (Giubileo and Pastore 2013a).

\subsection{Reorganizing the SWT}

Another condition for the EYG to work is that flexicurity be fully implemented, not only in terms of EPL, but also of ALMP. If the EYG means providing young people with employment or, at least, training opportunities, then there is not much in Italy with respect to this except a few training programs implemented at a regional level whose impact is negligible (Giubileo and Pastore 2013a).

The current Italian organization of the entire system is confusing: according to the 2001 reform of Title V of the Constitution, the state is in charge of the 
education system, through the Ministry of Education, regional bodies are in charge of the training system, and provinces (county-level authorities) are in charge of the PES. The EYG would need to re-structure the way regional bodies manage training programs.

The organization of PESs and their performance is very different across regions and also provinces. The situation should further evolve since provincial agencies will soon disappear, and a National Agency should be established to coordinate the activities of PES agencies. However, the current condition of uncertainty is also affecting the success of the EYG as already noted in Section 1.

Another important aspect is that ALMP should be properly targeted and the effectiveness of any intervention should be assessed with sound evaluation studies. Currently, Italy is one of the few advanced economies where statistical data for program evaluation is not collected at all. Some recent reforms - the Fornero Law, the Single Act on Apprenticeship, the Jobs Act and the EYG itself - have requested some form of monitoring of public spending, but no proper evaluation studies of the outcomes have been conducted. The new programs, including those implemented within the context of the EYG should also foresee some money for data collection and evaluation based on rigorous econometric methodologies.

More importantly, the unemployment and NEET rates are so high that it is necessary to think of some interaction of labor market institutions with the educational system and further restructuring of the current labor legislation.

The third problem is one of strongly targeting the EYG to those who can benefit more from it, which implies also coordinating the scheme with the existing tools. One of the most important novelties of labor policy in Italy was the approval, by unanimity vote, of the Consolidated Act on apprenticeships in September 2011 (for an overview of that legislation, see Tiraboschi 2011). It attempted to provide a solution to the youth experience gap and also to the failure of the temporary work legislation in providing adequate opportunities for young people to accumulate the work experience they need. In addition, using firm level data, Cappellari et al. (2012) find, for instance, that temporary work is generally associated with productivity losses, whereas apprenticeships are associated with productivity gains.

The act confirms the 2003 Biagi Law definition of three types of apprenticeship contracts: a) apprenticeship to gain a professional qualification or a craft; b) professional apprenticeship; c) high level apprenticeship. Type a is an alternative to dropping out of secondary high school for those students who do not wish to attend the standard technical or professional school. Type $b$ is the first three-year period of a permanent working contract, often post-secondary high school. Type $\mathrm{c}$ is for college graduates.

The apprenticeship law is inspired by the German system, but with an important difference: except for type a) apprenticeships, which are seen as a tool to prevent school dropout of a small minority rather than the main option in some types of schools, it is mainly a post-school, post-university program for young people up to the age of 29 years. $^{7}$ This means giving up an important aspect of the German model, namely the duality principle, which allows all young people not attending gymnasium to develop their competences and skills when they are still in education. Nonetheless, in the Italian labor market vacuum, allowing some form of interrelation between the training system and the labor market is in principle an important novelty. Another novelty is 
that university graduates can also be apprentices. This is an important novelty especially in consideration of the hardship that university education traditionally has in providing work related skills to university graduates.

Nonetheless, as the Ministry of Labor (2012) noted in one of its monitoring reports on the implementation of the apprenticeship law, against the expectations and the need for insertion jobs and on-the-job training of young people, that the number of apprenticeship places has been unexpectedly low in all regions of the country and has been further reducing during the crisis time. Apprenticeship contracts have, in fact, further reduced by about 50,000 places during the years from $2010(530,000)$ to 2012 $(470,000)$, probably because of the crisis. Figure 7 shows that apprenticeships are an opportunity for quite a large share of young people, about $14 \%$ in the country. This shows that the potential of these types of contracts is notable. The macro-areas where apprenticeship contracts are more widespread are the Center and the North-West. The South is the area where a lower share of contracts is signed, probably also because informal work is a better alternative for cost-saving strategies of firms located there.

The EU Commission (2003, Figure 2.1) provides comparative statistical information regarding the share of apprenticeship contracts in many EU27 countries based on the EU labor force survey in 2011, hence, before the economic crisis affected the labor market of most EU countries. According to this source of information, the share of apprentices in the youth population (aged 15-29) had in in Italy a medium incidence, defined as being an incidence of between 1.5 and 5\%. A similar share was also found in France, Poland and Portugal. Germany was the only country with a share bigger than $5 \%$. All other countries for which information was available had a share below $1.5 \%$. This suggests that the share of apprenticeship contracts is not particularly low in Italy, although still quite low, especially if compared to the needs of the EYG.

Despite its importance, the main reason why, the apprenticeship contract is not very widespread in Italy is that it is squeezed between two alternative solutions which are cheaper and more convenient for firms. On the one hand, other types of insertion contracts, such as stages and internships (tirocini formativi), are available where firms may

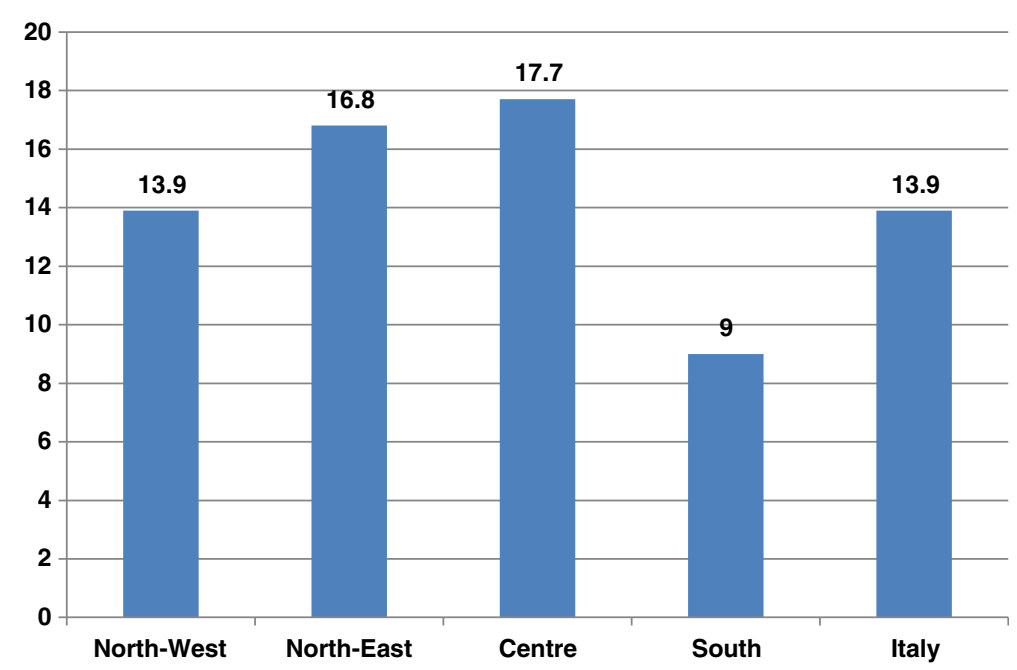

Figure 7 Share of apprentices over total employment by macro-area (2012). Source: own elaboration on ISTAT and INPS data. 
hire young people for a short time almost for free and with no obligation to provide on-the-job training to them. Instead, the apprenticeship program implies the undersigning of a training program agreed to by firms, education institutions, PESs and local authorities, which in some Italian regions is just very hard to do. On the other hand, temporary work contracts provide a much cheaper alternative for labor. A full functioning of the new apprenticeship law would be important for the successful implementation of the EYG, especially in consideration of the EU Commission recommendation, which points to apprenticeships as one of the main channels to implement the EYG. In order for the apprenticeship program to work properly, a number of authors (ISFOL 2012, 2013; Leonardi and Pallini 2013; D’Agostino 2014; Pastore 2014b, 2014c) have suggested that some conditions must be met:

a) apprenticeships should be made simpler for firms, introducing less muddled procedures;

b) other types of insertion contracts - stages, internships, short term contracts and so on - should be either eliminated or made more costly for firms;

c) the regional government should collaborate with firms to provide adequate training courses: again, this need calls for an empowerment of the PESs and a dramatic improvement of the quality of training courses;

d) some financial incentives should be provided to the firms which prefer apprenticeship to temporary contracts, such as tax relief on the wedge relative to apprentices, although this alone might also not be enough;

e) the educational system should be involved in the program, and apprenticeships should be offered to all those interested at the technical and professional high school.

Interestingly, the school reform that the Renzi government is currently going to approve, the so-called reform of the Buona scuola, foresees the obligation for every student enrolled in the technical and professional high school to undergo 200 hours per year of work in a firm (alternanza scuola lavoro). Until now, it has been allowed on an individual basis and initiative of every school, but only less than $1 \%$ of students used this opportunity. The role of apprenticeships as an alternative to compulsory education should be reinforced. It is within the agenda of Europe 2020 that the share of school dropouts should reduce. In Italy, school and university dropouts are a widespread social phenomenon (Gitto et al. 2012; Aina et al. 2013). For the EYG to be successful in Italy, it is necessary to assign to each institution its own role and mission. The EYG cannot be conceived for all the jobless individuals that are there in the country. Part of them need to complete their educational track, as Europe 2020 also suggests. To such an end, alternatives to general education should be provided. One such alternative could be incentives for firms to hire on apprenticeship contracts those who have dropped out of secondary high school without a qualification or for the other NEETs with a diploma or college degree.

Also universities should be involved in the school-to-work transition. The German type of professional universities could be an alternative for those young people who find it hard to get an academic university degree and come from technical or professional high school (Cappellari and Leonardi 2011, 2012). 


\section{Discussion and concluding remarks}

There are macro- and micro-economic factors of youth unemployment. Aggregate demand management (or the fight against austerity) is contrasted with structural reforms. Some observers, especially in North-European countries, call for aggregate demand management as an important pre-condition for the EYG to be successful. Without expansionary fiscal and monetary policy at the EU level, structural reforms may be ineffective in combating youth unemployment. The argument is that the EYG itself does not create new jobs. And nonetheless, North European countries were the first to introduce and implement the EYG. Other more liberalist observers argue in favor of the opposite line of reasoning: aggregate demand policy will not work unless there is more flexibility in the labor market and reductions in the cost of labor.

In fact, both arguments have some credence and, especially when youth unemployment is so massive as it is in Italy, all components of youth unemployment coexist: Keynesian, neoclassical, as well as frictional and mismatch unemployment. Keynesian unemployment, which is due to insufficient aggregate demand, has recently increased because of low economic growth. Without stimulating growth, the EYG is bound to fail as a tool to bring full employment.

Without some fiscal stimulus, the economic outlook will not be favorable to youth employment, despite the very low interest rates decided by the European Central Bank. But not simply any public spending will do. Public spending has increased in many Mediterranean countries in the last years, sometimes dramatically increasing public debt and hence worsening the budget constraint on public finances. In Italy, public debt has rapidly escalated from 103 percent in 2008 to over 130 percent of GDP today. And nevertheless, youth unemployment has further rocketed. This means that not simply any public spending is helping the youth. In fact, increasing public debt may be (though it does not need always be) contractionary if it forces to further increase taxes and if the new taxes eventually weigh on labor incomes, hence further depressing the already very low aggregate consumption. With the Maastricht criteria, public deficit soon becomes recessive for the economy because it is immediately followed by taxes. "Spend and tax" becomes almost instantaneous, not only because of the rational expectations of operators, as some macroeconomists would argue, but also because of the EU constraints on public debt.

A discussion on aggregate demand policy cannot escape the problem of where to find the necessary financial resources and therefore also deciding on the instruments to fight tax evasion and elusion or conducting an in-depth spending review. It is clear that the European Parliament should elaborate on criteria to implement an effective spending review both at the EU level and at the country level in order to free public resources for the implementation of the EYG. Labor income earners - the working and middle class already pay too many taxes and need alternatives to raising taxes on them to support social expenditure. Otherwise, it becomes a vicious circle which will quickly put our democracies under threat, like the last Italian political elections suggest.

What criteria should a spending review follow in Italy? To answer this question, it is important to consider that the origin of the crisis lies in the introduction of the Euro currency, which has produced many benefits but also some problems that many countries, especially the Mediterranean countries, have not been fully aware of. The move from a weak to a strong currency, from competitive devaluations to permanent 
monetary stability, has meant a dramatic loss of competitiveness for the manufacturing sector, which is the backbone of the economy in all Mediterranean economies. It is necessary to facilitate the on-going structural change by providing tools to move resources from the declining low technology sectors to the expanding high technology sectors, strengthening it through the provision of machinery endowed with advanced technology to traditional sectors, like the theory of endogenous growth would suggest. Money should be cut from traditional sectors and be concentrated on promoting education, research and development and innovation. Industrial policy should be resumed to support the development of advanced industrial sectors and in creating appropriate connections with traditional sectors, both for the transfer of new technologies and to facilitate the propagation of spillovers. This should also allow moving resources and jobs from traditional to high tech manufacturing.

These measures will not have a direct impact on neoclassical unemployment, which is due to the high cost of labor for firms. To such an end, instead of reducing wages, it would be important to improve the productivity of all production factors through the use of better technology and greater human capital. It is also important to reduce the labor wedge for firms because it is going to increase the income of wage employees actually available for consumption. It is possible to fight neoclassical unemployment by also reducing Keynesian unemployment if public resources are freed from alternative, less productive usages.

But also microeconomic reforms should be encouraged. In fact, youth unemployment was already high in the countries where it has increased more, such as the EuroMediterranean countries. The reason is that in these countries, other components of youth unemployment are also massive.

Without reforming labor market institutions, frictional and mismatch unemployment will remain high. Structural reforms, which are meant here not as a new labor market regulation but rather as the reinforcement of the PES and the re-organization of labor market institutions, will have several positive effects. First, they will reactivate many jobless young people, not only the unemployed, but also those out of the labor market. In turn, this will increase the number of tax payers and, indirectly, consumption by generating a redistribution of resources from high to low incomes and especially to the unemployed. This is in fact a pre-condition for a really expansionary fiscal policy.

Also, before the crisis exploded, Mediterranean countries experienced a dramatically high unemployment rate. One direction for a modern New Deal able to unite the interests of the low and the middle class could be that of increasing public spending on developing services which have been excluded in the past from the welfare state in South Mediterranean countries.

In Central and Northern European countries, the PESs work well, and there is a problem of reducing spending in passive and pro-active schemes. In Italy, youth unemployment is very high also because the educational system and the labor market do not provide sufficient guidance to young people. If the EYG eventually brings the number of young people who find a job through the PES to the German level, it would be a great success. And a full understanding of the inefficiencies of the educational and training system of Mediterranean countries strongly suggest that the jobs created through structural reforms would be additional, not substitutive, to existing jobs. 


\section{A list of priority areas}

This section aims to sum up the priority areas that have emerged from the previous analysis for a more successful implementation of the EYG in Italy:

a) Making austerity less binding, by:

a1) Excluding those components of public spending which are growth-enhancing from the accounting of the Maastricht criteria;

a2) Restructuring public spending in favor of more "productive" aims;

a3) Redistributing the fiscal weight in favor of labor incomes, which have shrunk by $15 \%$ of GDP in the last 20 years (Pastore 2010);

a4) Fighting tax evasion and elusion, which remain massive in the country.

b) Reducing the cost of labor, especially the taxes on labor incomes as well as social security contributions (Giubileo et al. 2014);

c) Reforming the labor market to implement a fully-fledged flexicurity system;

d) Introducing fiscal incentives for employers who hire on a permanent basis, especially young people;

e) Improving the institutions supervising the school-to-work transition system;

f) Making apprenticeships work more effectively by simplifying the procedures and reducing the relative cost as compared to alternative insertion contracts (Leonardi and Pallini, 2013);

g) Providing income support to the jobless young people on a contractual basis.

\section{Endnotes}

${ }^{1}$ Generally speaking, the People of Freedom is euro enthusiastic in Europe and eurosceptic in Italy.

${ }^{2}$ The electoral mechanisms of the two chambers are different. At the Camera, where all the over- 18 year-olds vote, the party who obtains the relative majority nationally gets $55 \%$ of the seats. At the Senate, where only the over- 25 s vote, a majority premium is assigned in each region. It means that the advantage of the government parties in terms of votes at the Senate is much smaller if the gap among leading and opposing parties is small and no party has a clear majority in all regions.

${ }^{3}$ There is a wide debate among Italian academics regarding the need to change in some way the EU macroeconomic policy. A number of economists proposed an appeal to ask the then Italian President of the EU, Matteo Renzi, to launch a new Bretton Woods conference of Europe (Becchetti et al. 2014). Gallegati (2014) suggests reforming the EU's institutions and foreseeing stronger forms of support to the public finances of the weakest countries. Pastore (2014a) suggests to overcome the Maastricht Treaty at least to allow member states to implement the Lisbon strategy.

${ }^{4}$ See the recent self-assessment of her experience as a Minister of Labor: Forenro (2013).

${ }^{5}$ The proposal of a single contract is due to Tito Boeri and Pietro Garibaldi (2007, 2010) in a number of contributions published on www.lavoce.info.

${ }^{6} \mathrm{http}: / /$ ec.europa.eu/eurostat/statistics-explained/index.php/School-to-work_transition statistics

${ }^{7}$ Although already from 2003, the apprenticeship contract of type one has been an alternative to compulsory education for those who require it, nonetheless, as a matter of fact, it has been rarely used and is not integrated in the educational system. 


\section{Abbreviations}

5SM: 5 Star Movement; ALMP: Active Labor Market Policy; ECB: European Central Bank; EPL: Employment Protection Legislation; EU: European Union; EYG: European Youth Guarantee; GDP: Gross Domestic Product; IMU: Imposta Municipale Unica; NEET: Not in Employment Education and Training; PES: Public Employment Service; PLMP: Passive Labor Market policy; SWTS or SWTR: School-t-Work Transition System or Regime.

\section{Competing interests}

The IZA Journal of European Labor Studies is committed to the IZA Guiding Principles of Research Integrity. The author declares that he has observed these principles.

\section{Authors' information}

Short bio of the author: Francesco Pastore [Ph.D. (Sussex); Dottorato ("Federico II"); M.Sc. (Coripe-Piemonte); Laurea ("Federico II")] qualified as full professor of Economic Policy and as Associate Professor of Economics (2013) and Economic Statistics (2014). Currently, he is Associate Professor at Seconda Università di Napoli; research fellow of the IZA of Bonn; the Secretary of the Italian Association of Labor Economists; and a member of the executive board of the Italian Association of Comparative Economic Studies. He has acted as a consultant for, among others, the EU Commission, ILO, UNDP and World Bank. He has published two edited books for Springer Verlag, three special issues of the International Journal of Manpower and a large number of articles in such journals as, among others: Journal of Economic Surveys, Stata Journal, Economics of Education Review, Economics of Transition, Annals of Public and Cooperative Economics, Post-Communist Economies.

\section{Acknowledgements}

The content of this paper has been the object of discussion with a number of colleagues. The author wishes to thank in particular Luisa Corazza, Hans Dietrich, Achille Flora, Francesco Giubileo, Lisa Rustico, Silvia Spattini, Jutta Steinruck, a member of the editorial board, Martin Kahanec, as well as an anonymous referee for useful comments and suggestions on an earlier draft. This notwithstanding, the usual disclaimer applies.

Responsible editor: Martin Kahanec

Received: 16 November 2014 Accepted: 26 February 2015

Published online: 26 May 2015

\section{References}

Aina C, Baici E, Casalone G, Pastore F (2013) II fuoricorsismo fra falsi miti e realtà. Economia Lavoro 47(1):147-154 Albertini M, Impicciatore R, Tuorto D (2013) "Un Grillo nella testa dei giovani", lavoce.info, 5 Marzo

Aristotelous K (2006) Are There Differences across Countries Regarding the Effect of Currency Unions on Trade? Evidence from EMU. J Common Mark Stud 44(1):17-27

Becchetti L, Cellini R, Pini P, Zazzaro A (2014) "L'Italia chieda una Bretton Woods per l'eurozona", Letter directed to the President of the EU, 13th of october

Bell DNF, Blanchflower DG (2015) Youth unemployment in Greece: measuring the challenge. IZA J Eur Labor Stud 4:1 Besamusca J, Stănescu I, Vauhkonen J (2012) The European Youth Guarantee: a reality check. Renner Institut, Brussels Boeri T (2013) "Licenziamenti e legge Fornero", lavoce.info, 15 giugno

Boeri T, Garibaldi P (2007) II testo unico del contratto unico. www.lavoce.info, 19th of October

Boeri T, Garibaldi P (2010) Tutti i vantaggi del contratto unico. www.lavoce.info, 23rd of April

Cahuc P, Carcillo S, Rinne U, Zimmermann K (2013) Youth unemployment in Old Europe: the polar cases of France and Germany. IZA J Eur Labor Stud 2:18

Cappellari L, Leonardi M (2011) A favore delle fachhochschulen. www.nelmerito.com, 14th of October

Cappellari L, Leonardi M (2012) "A favore di un sistema di vocational tertiary education in Italia", con L. Cappellari, in "Giovani senza futuro? Proposte per una nuova politica", in C. Dell'Aringa and T.Treu (eds.), AREL-II Mulino.

Cappellari L, Dell'Aringa C, Leonardi M (2012) Temporary employment, job flows and productivity: a tale of two reforms. Econ J 122(562):F188-F215

Cicciomessere R (2014) "Le capacità d'intermediazione degli operatori pubblici e privati del lavoro: criticità e proposte per superarle", audition at: Camera dei deputati - Indagine conoscitiva sulla gestione dei servizi per il mercato de lavoro e sul ruolo degli operatori pubblici e privati, XI Commissione (Lavoro pubblico e privato), September

Cicciomessere R, Sorcioni EM (2007) La collaborazione fra gli operatori pubblici e privati. Italia Lavoro, Roma

D'Agostino S (2014) Formazione in apprendistato. C'è o non c'è?. www.learning4.it, 2nd of May

Diamanti I (2012) "Ė ora di restituire lo stato ai cittadini", La Repubblica, 9th of January

Dietrich D (2013) Youth Unemployment in the Period 2001-2010 and the European Crisis - Looking at the Empirical Evidence. Transf 19(3):305-324

EU Commission (2003) Apprenticeship and traineeship schemes in EU27: key success factors. EU Union, Brussels, December

Fornerno E (2013) Reforming labor markets: reflections of an economist who (unexoectedly) became the Italian Minister of Labor. IZA J Eur Labor Stud 2:20

Gallegati M (2014) "L'Euro e la doppia illusione della moneta", sbilanciamoci.it, 1 Aprile

Gitto L, Minervini LF, Monaco L (2012) "University Dropouts: Supply-side Issues in Italy", MPRA discussion papers, N. 56656, September.

Giubileo F (2011) Due o più modelli di politiche del lavoro in Europa? I servizi del lavoro in Italia, Germania, Francia, Svezia e Regno Unito. Rivista Del Diritto Della Sicurezza Sociale 3(4):759-777

Giubileo F (2012) La via inglese al collocamento. www.lavoce.info, 9th of March

Giubileo F, Leonardi M, Pastore F (2014) Se la Garanzia giovani diventa un servizio civile. www.lavoce.info, 29 luglio

Giubileo F, Pastore F (2012) Un call centre per trovare lavoro. lavoce.info, 19th of October 
Giubileo F, Pastore F (2013a) Una garanzia europea per i giovani. lavoce.info, 11th of June Giubileo F, Pastore F (2013b) Quale futuro per i centri per l'impiego?. lavoce.info, 25th of October

Giubileo F, Pastore F (2013c) Centri per l'impiego, il pubblico non basta. lavoce.info, 21th of November

Giuliani L Pastore F (2014) "The European School-to-Work Transition and the Crisis", Social Europe Journal, 16th of September

Giuliani L, Pastore F (2015) The Determinants of Youth Unemployment. A Panel Data Analysis", XXIX AIEL Conference. University of Pisa, Pisa

Guiso L (2014) Effetti del bonus da 80 euro: calcolare con cura. www.lavoce.info, 28th of October

ISFOL (2012) XIII Rapporto di monitoraggio sull'apprendistato. ISFOL, Roma

ISFOL (2013) XIV Rapporto di monitoraggio sull'apprendistato. ISFOL, Roma

Leonardi M, Pallini EM (2013) Difficile e burocratico, l'apprendistato non decolla. www.linkiesta.it, 3 giugno

Mandrone E (2011) La ricerca del lavoro in Italia: l'intermediazione pubblica, privata e informale. Politic Econ 27(1):83-124

Ministry of Labor (2015) $38^{\circ}$ Report settimanale - Aggiornamento al 12 Febbraio. Garanzia Giovani, Rome

Ministry of Labor (2012) Monitoraggio sull'apprendistato. XIII Rapporto, Rome

Paparo A, Cataldi M (2013) "Flussi fra Camera e Senato: fra i giovani crollo del PD e successo del M5S", Centro Italiano Studi Elettorali, 14th of March. http://cise.luiss.it/cise/2013/03/14/il-voto-dei-giovani-nellanalisi-dei-flussi-elettorali-fracamera-e-senato/

Pastore F (2010) Assessing the impact of incomes policy. The Italian experience. Int J Manpow 31(7):793-817

Pastore F (2012) "Youth Unemployment in Italy at the Time of the Great Depression", Friedrich Ebert Stiftung, discussion paper.

Pastore F (2013) "Employment Services in View of the School-to-Work Transition. A Comparative Analysis" FORMEZ, Area comunicazione e servizi al cittadino, Rome.

Pastore F (2014a) Oltre la flessibilità: Dai parametri di Maastricht a quelli di Europa 2020. www.nelmerito.com, 28th of July

Pastore F (2014b) II difficile percorso dell'apprendistato. www.lavoce.info, 5th of May

Pastore F (2014c) Jobs Act e apprendistato. Una semplificazione obbligata in attesa del secondo tempo. www.learning4.it, 27th of March

Pastore F (2015) The Youth Experience Gap. Explaining National Differences in the School-to-Work Transition. Springer Verlag, SpringerBriefs in Economics, Heidelberg

Pittella G (2015) Un'inversione di tendenza in Europa. www.nelmerito.com, 9th of February

Quintini G, Martin JP, Martin S (2007) The changing nature of the school-to-work transition process in OECD countries. IZA Discussion Paper, no. 2582, January

Rocha Sanchez F (2012) Youth Unemployment in Spain: Situation and Policy Recommendations. Friedrich Ebert Stiftung, discussion paper

Tiraboschi M (2011) Testo Unico dell'apprendistato e le nuove regole sui tirocini. Giuffrè, Milan

Tiraboschi M (2015) A Guarantee that is not there (yet). Adapt University Press, Bergamo

Tubadji A (2012) Youth unemployment in Greece: economic and political perspectives", Friedrich Ebert Stiftung, discussion paper

\section{Submit your manuscript to a SpringerOpen ${ }^{\circ}$ journal and benefit from:}

- Convenient online submission

Rigorous peer review

- Immediate publication on acceptance

- Open access: articles freely available online

- High visibility within the field

Retaining the copyright to your article 